Al-Huquq: Journal of Indonesian Islamic Economic Law, 3 (1), 2021: 34-51

ISSN: 2715-0003; E-ISSN 2714-5514

DOI: http://doi.org/10.19105/alhuquq.v3i1.3886

\title{
Transaksi Jual Beli Sepeda Motor Bekas dengan Akad Salam di Desa Tamberu Laok
}

\author{
Agung Kurniawan, Moh. Rasyid \\ (Fakultas Syariah dan Hukum UIN Sunan Kalijaga Yogyakarta, Jl. Marsda \\ Adisucipto Yogyakarta 55281)
}

\begin{abstract}
Abstrak:
Praktik jual beli sepeda motor bekas yang terjadi di Desa Tamberu Laok dapat disimpulkan belum sesuai dengan kaidah-kaidah akad salam, mengingat banyaknya keluhan dari pembeli sebagai pihak yang dirugikan. Fenomena tersebut, karena itu, menjadi isu menarik untuk diteliti guna memberikan landasan metodologis-ilmiah yang beririsan dengan ketentuan-ketentuan fiqh muamalah. Dengan menggunakan metode wawancara, jenis penelitian field research ini merumuskan dua masalah yang menjadi obyek kajian; pertama, tentang transaksi jual beli sepeda motor bekas di Desa Tamberu Laok, Kec. Sokobanah, Kab Sampang, dan kedua, bagaimana elaborasi atau pandangan akad salam terhadap transaksi jual beli sepeda motor bekas tersebut. Hasil temuan penulis dapat dilihat dalam dua hal, pertama, dalam pembelian sepeda motor bekas, pembeli memesan kepada pedagang dan membayar separuh harga terlebih dahulu. Kedua, dalam praktek transaksinya, ditemukan ketidaksesuaian dengan akad salam. Ketidaksesuaian tersebut dapat dilihat ketika barang pesanan tidak sesuai dengan permintaan awal, sementara transaksi tetap berlangsung dan tidak ada pembatalan. (The practice of buying and selling a second-hand motorbike in the village of tamberu laok is not in harmony with the principle of Salam contract, in view of the heavy complaints of customers as aggrieved sides. The phenomenon, therefore, is an interesting issue for research on the basis of scientific methodologies filleted with terms of the fiqh muamalah. Using methods of interviews, this type of field research defined two issues that are subject of study; the first is about the sale of a second-hand motorcycle in the village of Tamberu Laok, kec. Sokobanah, kab Sampang, and the second is how the elaboration or viewpoint of Salam contract towards of the second-hand motorcycle sales transactions. The writer's findings can be seen in two respects,
\end{abstract}

email koresproden: kurniawanagung771@gmail.com

https://creativecommons.org/licenses/by-nc/4.0/

Copyright (c) 2019 by al-huquq. All Right Reserved 
Transaksi Jual Beli Sepeda Motor Bekas dengan Akad Salam di Desa Tamberu Laok

first, in the purchase of second-hand motorcycles, the buyer orders to the merchant and previously pays the half price. Secondly, in the practice of the transaction, there was a inconsistency with the Salam contract. That inconsistency can be seen when the order item is not suitable with the first request, the transaction will go on and there is no annulment).

\section{Kata Kunci:}

Jual Beli, Akad Salam, Sepeda Motor, Sampang

\section{Pendahuluan}

Praktik jual beli merupakan salah satu perilaku yang sangat akrab dengan kebutuhan manusia dalam rangka keberlangsungan hidup. Secara terminologi yang umum, jual beli, dimaknai sebagai prilaku tukar menukar uang dengan barang atau obyek jual beli. Dalam kitab Undang-Undang Hukum perdata Islam KUHPI (Manjalla Al-Ahkam Al-Adaliyah), misalnya, yang dimaksud dengan akad jual beli (al-bai') adalah pertukaran harta dengan harta, bisa bersifat mengikat (mun'aqid) dan tidak mengikat (ghair mun'aqid). ${ }^{1}$ Sementara dalam literatur fiqh muamalah, jual beli berarti tukar menukar harta yang dibangun atas dasar saling ridha (rela), atau memindahkan kepemilikikan dengan imbalan pada sesuatu yang diizinkan oleh syariat. $^{2}$

Menurut pandangan fuqaha Malikiyah, jual beli dapat diklasifikasikan menjadi dua macam, yaitu jual beli yang bersifat umum dan jual beli yang bersifat khusus. Jual beli dalam arti umum ialah suatu perikatan tukar-menukar sesuatu yang bukan kemanfaatan dan kenikmatan. Artinya, sesuatu yang bukan manfaat ialah benda yang ditukarkan adalah berupa dzat (berbentuk) dan ia berfungsi sebagai objek penjualan, jadi bukan manfaatnya atau bukan hasilnya. Sedangkan jual beli dalam arti khusus, ialah ikatan tukarmenukar sesuatu yang mempunyai kriteria antara lain, bukan kemanfaatan dan bukan pula kelezatan yang memiliki daya tarik, penukarannya bukan emas dan bukan pula perak, bendanya dapat

1 Burhanuddin S, Hukum Kontrak Syariah (Yogyakarta: BPFEYogyakarta, 2009)., hlm 68.

2 Ascarya, Akad \& Produk (Jakarta: RajaGrafindo Persada, 2007)., hlm. 76. 
direalisis dan tidak ditangguhkan, tidak merupakan hutang baik barang tersebut ada di hadapan si pembeli maupun tidak dan barang tersebut telah diketahui sifat-sifatnya atau sudah diketahui terlebih dahulu. ${ }^{3}$

Dari sisi pembayarannya, jual beli dibagi menjadi empat, yaitu: 1) jual beli tunai dengan penyerahan barang dan pembayaran langsung. 2) jual beli dengan pembayaran tertunda, bai' nuajjal (deferred payment), yaitu jual beli dengan penyerahan barang secara langsung (tunai), tetapi pembayaran bisa dilakukan kemudian dan bisa dicicil. 3) jual beli dengan penyerahan barang tertunda bai' assalam (deferred delivery), yaitu jual beli ketika pembeli membayar tunai di muka atas barang yang dipesan dengan spesifikasinya yang akan diserahkan kemudian. 4) Jual beli dengan penyerahan barang dan pembayaran sama-sama tertunda. ${ }^{4}$

Sehubungan dengan fenomena mutaakhir yang belakangan berkembang di Desa Tamberu Laok, Kec. Sokobanah, Kab. SampangMadura, praktik jual beli dengan model pembayaran yang ketiga ( $b a i^{\prime}$ as-salam) yang rupanya banyak diterapkan. Adalah jual beli sepeda motor bekas dengan cara, si pembeli memesan terlebih dahulu kepada pedagang dengan membayar DP terlebih dahulu dan barangnya ditangguhkan. Dalam kajian fiqh muamalah, model jual beli seperti ini disebut salam. Akad salam adalah bentuk jual beli dengan pembayaran di muka sementara penyerahan barang di kemudian hari dengan harga, spesifikasi, jumlah, kualitas, tanggal dan tempat penyerahan yang jelas, serta disepakati sebelumnya dalam perjanjian. ${ }^{5}$

Secara pragmatis dan sepintas apa yang terjadi dalam jual beli di Desa Tamberu Laok ini sudah sesuai dengan ketentuan normatif fiqh muamalah-dalam hal ini akad salam. Namun demikian dalam fakta empiris di lapangan, tidak menutup kemungkinan terjadinya kecenderungan lain yang justru tidak sejalan dengan ketentuan fiqh.

${ }^{3}$ Qamarul Huda, Figh Muamalah (Yogyakarta: Teras, 2011)., hlm. 53.

${ }^{4}$ Ascarya, Akad \& Produk, (Jakarta: RajaGrafindo Persada, 2007)., hlm. 78.

${ }^{5}$ Ibid, hlm. 90. 
Transaksi Jual Beli Sepeda Motor Bekas dengan Akad Salam di Desa Tamberu Laok

Adanya keluhan dari salah seorang pembeli sepeda motor bekas, ${ }^{6}$ misalnya, akan memperkuat fakta itu. Sebagai contoh kecil, ketika si pembeli memesan sepeda motor dengan warna dan tahun tertentu dan pada saat penyerahan, ternyata barang tersebut tidak sesuai dengan permintaan dan kesepakatan diawal. Kendati demikian, transaksi jual beli tersebut tetap berjalan. Oleh karena itu penulis akan mencoba meneliti lebih jauh fenomena tersebut menggunakan akad salam sebagai pisau analisisnya.

Secara spesifik dan rinci, fokus penelitian ini sekurangkurangnya dapat dilihat dalam dua rumusan besar, 1) bagaimana transaksi jual beli sepeda motor bekas di Desa Tamberu Laok, Kec. Sokobanah, Kab Sampang? 2) bagaimana elaborasi atau pandangan akad salam terhadap transaksi jual beli sepeda motor bekas yang berlangsung di Desa Tamberu Laok, Kec. Sokobanah Kab. Sampang?

Selain alasan-alasan pragmatis akan pemahaman terhadap suatu fenomena sosial-keagamaan, serta penguasaan terhadap prinsip-prinsip dasar fiqh muamalah, urgensitas penelitian ini juga terletak pada kontribusinya guna memberikan landasan konseptualmetodologis ilmiah kepada khalayak pada umumnya, dan masyarakat Tamberu Laok, Kec. Sokobanah, Kab. Sampang pada khususnya. Sehingga dengan demikian, pada akhirnya masyarakat muslim, khususnya di pedesaan, akan lebih berhati-hati dalam menjalankan praktik-praktik jual beli dengan pihak lain, sehingga tidak membuka peluang atas terjadinya berbagai bentuk transaksi yang justru melabrak ketentuan-ketentuan syariat Islam.

\section{Metode Penelitian}

Jenis penelitian ini adalah penelitian lapangan atau field research. Dalam penelitian field research pada umumnya, peneliti melakukan pengamatan langsung ke lapangan untuk memotret fakta-fakta empiris yang terjadi baik itu berupa orang, komunitas, lembaga, dan sebagainya yang memungkinkan dijadikan obyek penelitian. Adapun pendekatan yang digunakan adalah pendekatan kualitatif-deskriptif,

${ }^{6}$ Kaitannya dengan hal ini, penulis sudah melakukan wawancara langsung ke desa tamberu laok, dan sudah mengantongi beberapa data yang secara khusus akan dipaparkan di penyajian data dalam sub-tema pembahasan. 
yaitu, penulis mendeskripsikan baik kata-kata maupun tindakan obyek penelitian yang penulis amati selama proses penelitian. ${ }^{7}$

Oleh karena jenis penelitian ini field research dengan pendekatan kualitatif, maka sumber data yang digunakan adalah fakta riil yang terjadi di lapangan. Lofland, sebagaimana yang dikutip oleh Buna'i, mengemukakan bahwa sumber data mendasar dalam penelitian kualitatif adalah kata-kata dan tindakan suatu obyek penelitian, selebihnya berupa data-data tambahan seperti buku, artikel, atau dokumen lainnya yang relevan. ${ }^{8}$

Selain itu, sumber data yang digunakan dalam penelitian ini terbagi ke dalam dua bagian; data primer dan data sekunder. Data primer adalah data terpenting yang diperoleh melalui pengamatan penulis pada saat wawancara dan observasi di lapangan. ${ }^{9}$ Dalam konteks ini, maka hasil wawancara dan observasi penulis di Desa Sokobanah Laok, Kec. Sokobanah, Kab. Sampang secara otomatis akan menjadi sumber primer penelitian. Sementara data sekunder merupakan data tambahan yang diperoleh dari sumber tertulis lainnya yang bersangkut-paut dengan persoalan yang sedang diteliti.

Setelah data terkumpul, langkah berikutnya yang penulis lakukan adalah analisis data. Analisis data yang digunakan adalah analisa kualitatif, atau tepatnya menganalisa data yang sudah terkumpul. Menurut Bogdan \& Biklan sebagaimana yang dikutip oleh Imam Gunawan, analisis data adalah proses pencarian dan pengaturan secara sistematik hasil wawancara, catatan-catatan, dan dokumentasi untuk memperoleh pemahaman-pemahaman generik dari semua hal yang dikumpulkan dan ditemukan tersebut. ${ }^{10}$ Untuk lebih jelasnya, berikut rincian dari tahapan analisis data dalam penelitian ini;

Pertama, data reduction. Mereduksi data umumnya dilakukan dengan cara merangkum, mengidentifikasi bagian-bagian pokok,

7 Lexi J. Moleong, Metodologi Penelitian Kualitatif (Bandung: Remaja Rosda Karya, 2014)., hlm. 4.

8 Buna'i, Buku Ajar Metodologi Penelitian Pendidikan (Pamekasan: STAIN Pamekasan Press, 2006)., hlm. 16.

${ }^{9}$ Lexi J. Moleong, Metodologi Penelitian Kualitatif, hlm. 157.

${ }^{10}$ Imam Gunawan, Metode Penelitian Kualitatif Teori \& Praktik (Malang: Bumi Aksara, 2013)., hlm. 160. 
Transaksi Jual Beli Sepeda Motor Bekas dengan Akad Salam di Desa Tamberu Laok

memfokuskan pada hal-hal yang penting, dan mencari tema beserta polanya. Dengan demikian maka akan memperoleh gambaran yang jelas dan memudahkan untuk melakukan pengumpulan data. Karenanya temuan yang dipandang asing, tidak dikenal dan belum memiliki pola, maka akan menjadi perhatian serius mengingat tujuan penelitian kualitatif untuk mencari pola yang tersembunyi dibalik pola dan data yang sudah nampak jelas di permukaan.

Kedua, data display. Teknik ini sangat penting untuk menyusun berbagai informasi atau temuan baru yang diperoleh. Penyajian data dimaksudkan untuk memperoleh pemahaman terhadap suatu kasus secara komprehensif, sebelum akhirnya menyimpulkan temuantemuan yang diperoleh tersebut.

Ketiga, conclusion/verifying. Langkah terakhir dalam teknik analisis data ini adalah mengambil kesimpulan dari hasil penelitian. Sebab penarikan kesimpulan merupakan hasil penelitian yang menjawab rumusan-rumusan masalah yang diajukan berdasarkan analisis data. ${ }^{11}$

\section{Gambaran Akad Salam}

Sebelum menjelaskan tentang salam, penulis akan sedikit menyinggung apa itu jual beli secara definitif. Secara etimologis, jual beli artinya mengganti dan menukar sesuatu dengan sesuatu yang lain. Sedangkan secara terminologis, ulama Hanafiyah mendefinisikan jual beli sebagai saling menukar harta dengan harta melalui cara tertentu, atau tukar menukar sesuatu yang diinginkan dengan yang sepadan melalui cara tertentu yang bermanfaat. ${ }^{12}$

Dalam fiqh muamalah, jual beli pesanan dikenal sebagai " $a s^{-}$ salam" khususnya dalam tradisi penduduk hijaz, sedangkan dalam tradisi penduduk iraq, disebut "as-salaf". Secara etimologis duaduanya memiliki makna yang sama, dan pernah digunakan langsung

oleh Nabi Muhammad SAW. Ketika membicarakan bai'as-salam atau

${ }^{11} \mathrm{Ibid}, \mathrm{hlm} .210-212$.

${ }_{12}$ Muhammad Djakfar, Hukum Bisnis (Malang: UIN Malang Press, 2009),. hlm. 172. 
akad salam, Nabi menggunakan term as-salaf dan juga term as-salam. ${ }^{13}$ Dua kata tersebut, karenanya, merupakan sinonim. Secara terminologi fuqaha' mendefinisikan akad salam sebagai jual beli barang yang penyerahannya ditunda, tetapi ciri-cirinya jelas dengan pembayaran modal diawal, sedangkan barangnya diserahkan di kemudian hari. ${ }^{14}$

Salam adalah akad jual beli barang pesanan antara pembeli dan penjual dengan pembayaran dilakukan di muka pada saat akad dan pengiriman barang dilakukan pada saat akhir kontrak. Barang pesanan harus jelas spesifikasinya. Spesifikasi barang telah disepakati oleh pembeli dan penjual di awal akad. Barang pesanan harus sesuai dengan karakteristik yang telah disepakati. ${ }^{15}$

Ulama-ulama figh Hanabilah dan Syafi'iyah mendefinisikan salam sebagai akad yang telah disepakati ciri-cirinya dengan membayar harganya terebih dahulu, sedangkan barangnya diserahkan kepada pembeli dikemudian hari. ${ }^{16}$ Sementara itu, para ulama fiqh Malikiyah mendefinisikannya sebagai jual beli yang modalnya dibayar terlebih dahulu, sedangkan barangnya diserahkan sesuai dengan waktu yang telah disepakati. ${ }^{17}$ Dengan demikian, akad salam, termasuk kategori jual beli yang sah sepanjang memenuhi persyaratan keabsahan jual beli pada umunya. ${ }^{18}$

Kata as-salam juga disebut dengan as-salaf, yang berarti, menjual sesuatu dengan sifat-sifat tertentu, masih dalam tanggung jawab pihak penjual tetapi pembayaran segera atau tunai. Para ulama fiqh menamakannya dengan istilah al-Mahawi'ij. Artinya, adalah sesuatu yang mendesak, karena dalam jual beli tersebut barangnya tidak ada

${ }^{13}$ Biuty Wulan Octavia, "Tinjauan Hukum Islam Terhadap Jual Beli Akad As-Salam Dengan Sistem On Line Di Pand's Collection Pandanaran" (Institut Agama Islam Negeri Walisongo Semarang, 2011),. hlm. 16.

14 Nasrun Haroen, Figh Muamalah (Jakarta: Gaya Media Pratama, 2007),. hlm. 147.

${ }^{15}$ Ismail, Perbankan Syariah (Jakarta: Kencana Prenadamedia Group, 2011),. hlm. 152.

16 Osmad Muthaher, Akutansi Perbankan Syariah (Yogyakarta: Graha Ilmu, 2012), . hlm. 77.

17 Ibid.

18 Mardani, Figh Muamalah (Jakarta: Kencana Prenadamedia Group, 2012), hlm. 113. 
di tempat, sementara dua belah pihak yang melakukan jual beli dalam keadaan terdesak. Pembeli atau pemilik uang membutuhkan barang, sementara pemilik barang membutuhkan uang untuk memenuhi kebutuhannya. ${ }^{19}$

Adapun rukun salam menurut fuqaha Hanafiyah, hanya ijab dan qabul. Sedangkan menurut fuqaha lainnya, rukun salam itu ada empat, 1) pihak-pihak yang berakad, yaitu muslam (pembeli/pemesan) dan muslam ilayhi (penjual/pemasok). 2) barang yang dipesan (muslam fihi). 3) modal atau atau uang. 4) sighat akad (ijab dan kabul).

Adapun syarat sahnya akad salam adalah sebagai berikut; 1) pihak-pihak yang berakad disyaratkan dewasa, berakal, dan baligh. 2) barang yang dijadikan objek disyaratkan jelas jenis, ciri-ciri, dan ukurannya. 3) modal atau uang disyaratkan harus jelas dan terukur serta dibayarkan seluruhnya ketika berlangsungnya akad. 4) ijab dan qabul harus diungkapkan dengan jelas, sejalan, dan tidak terpisah oleh hal-hal yang dapat memalingkan keduanya dari maksud akad. ${ }^{20}$

Sementara itu, dalam Kompilasi Hukum Ekonomi Syariah, Pasal 101 s/d Pasal 103, bahwa syarat-syarat bai'salam adalah; 1) bai' salam dapat dilakukan dengan syarat kuantitas dan kualitas barang yang sudah jelas. 2) kuantitas barang dapat diukur dengan takaran atau timbangan dan/atau meteran. 3) spesifikasi barang yang dipesan harus diketahui secara sempurna oleh para pihak. 4) bai' salam harus memenuhi syarat bahwa barang yang dijual, waktu, dan tempat penyerahan dinyatakan dengan jelas. 5) pembayaran barang dalam bai' salam dapat dilakukan pada waktu dan tempat yang disepakati. ${ }^{21}$

Kitab suci al-Qur'an sendiri memberikan landasan normatif atas kebolehan akad salam, sebagaimana yang dijelaskan QS. Al-Baqarah (2): 282 .

Artinya: Hai orang-orang yang beriman, apabila kamu bermu'amalah tidak secara tunai untuk waktu yang ditentukan, hendaklah kamu menuliskannya. ${ }^{22}$

19 Siti Mujiatun, "Jual Beli Perspektif Islam Salam Dan Istishna," Jurnal Riset Akutansi Dan Bisnis 13 (2013): 207.

20 Osmad Muthaher, Akutansi Perbankan Syariah., hlm. 86.

${ }_{21}$ M. Fauzan, Kompilasi Hukum Ekonomi Syariah (Jakarta: Kencana Pranada Media Group, 2009),. hlm. 42.

${ }^{22}$ Al-Qur'an, Al-Baqarah (2): 282. 
Adapun dalil yang lain, adalah hadits Nabi yang dikutip Mardani dalam bukunya, yang diriwayatkan oleh Ibnu Abbas, bahwa Rasulullah SAW datang ke Madinah dimana penduduknya melakukan salaf (salam) dalam buah-buahan untuk jangka waktu satu, dua, dan tiga tahun. Rasul bersabda, "barang siapa yang melakukan salaf (salam), hendaklah ia melakukan dengan takaran yang jelas dan timbangan yang jelas pula, untuk jangka waktu yang ditentukan." Dalam hadits lain: Dari Shihab r.a, bahwa Rasulullah SAW bersabda: "tiga hal yang di dalamnya terdapat keberkahan: jual beli tangguhan, muqaradhah (mudharabah), dan mencampur gandum dengan tepung untuk keperluan rumah, bukan untuk di jual" (HR. Ibnu Majjah). ${ }^{23}$

\section{Transaksi Jual Beli Sepeda Motor Bekas di Desa Tamberu Laok Kec. Sokobanah Kab. Sampang}

Kebutuhan masyarakat khususnya di Desa Tamberu Laok makin hari semakin menemukan puncaknya. Hal ini yang pada gilirannya menuntut mereka untuk melakukan transaksi jual beli dengan pihak-pihak lain guna memenuhi kebutuhannya tersebut. Satu dari sekian bentuk transaksi yang dimaksud adalah jual beli sepeda motor bekas dimana model pembeliannya melalui pedagang terlebih dahulu. ${ }^{24}$ Berdasarkan hasil penelitian penulis, model pembelian yang mereka pilih dilatarbelakangi oleh kepercayaan mereka kepada pedagang, selain mereka sendiri tidak banyak tahu masalah harga di pasaran dan sepeda motor bekas yang masih berkualitas. ${ }^{25}$

Dalam proses pemesanan barang, terdapat kesepakatankesepakatan khusus antara pembeli dan pedagang baik dari segi harga, spesifikasi dan kualitas sepeda motor yang hendak dipesan.

${ }^{23}$ Mardani, Fiqh Muamalah., hlm. 115.

24 Hasil wawancara penulis dengan ahmad dan mahrus, warga setempat yang sekaligus penjual sepeda motor bekas terkenal di desa tersebut. wawancara secara langsung dilakukan pada tanggal 17 januari 2019 pukul 10:22 wib.

25 Wawancara Penulis Dengan Wahyudi, Warga Setempat Yang Sekaligus Pembeli Sepeda Motor Bekas, Wawancara Secara Langsung Pada Tanggal 19 Januari 2019 Pukul 16:10 WIB. 
Transaksi Jual Beli Sepeda Motor Bekas dengan Akad Salam di Desa Tamberu Laok

Setelah proses pemesanan selesai, maka si pembeli hanya menunggu sampai barang pesanannya datang. ${ }^{26}$

Dalam transaksi jual beli apapun, tak terkecuali dalam akad salam, adanya kesepakatan antara kedua belah pihak menjadi prasyarat utama yang secara normatif sudah diatur dalam fiqh muamalah. Selain untuk memenuhi ketentuan fiqh, adanya perjanjian atau yang lumrah disebut akad (ijab dan qabul) juga dimaksudkan untuk menghindari terjadinya hal-hal yang tidak diinginkan dalam transaksi. Dalam konteks jual beli sepeda motor bekas di Desa Tamberu, bentuk kesepakatan tersebut terjadi pada saat pemesanan barang. Setelah calon pembeli menjelaskan secara rinci spesifikasi (meliputi merek, tahun, hingga warna) barang (sepeda motor) yang diinginkan, penjual kemudian menjelaskan harga standart di pasaran dari barang yang dipesan. Setelah langkah tersebut sama-sama disepakati, pembeli harus membayar separuh harga atau sekitar 50\% dari harga yang ditentukan penjual. ${ }^{27}$ Setelah pembayaran separuh harga selesai, maka pembeli menentukan kapan sepeda motor yang dipesan tersebut akan diserahkan" ${ }^{28}$

Kendati demikian, ketidaksesuaian suatu kesepakatan dengan fakta yang terjadi setelahnya setidaknya seringkali terjadi dalam sebuah transaksi, tak terkecuali dalam hal jual beli sepeda motor bekas yang terjadi di Desa Tamberu Laok ini. Seperti halnya yang pernah dialami oleh Rusdi, warga setempat yang sekaligus pembeli sepeda motor bekas. Rusdi pernah memesan sepeda motor bekas merek Vario tahun 2015, dengan harga sekitar Rp. 19.000.000. Pada saat pedagang menyerahkan sepeda motor pesanan Rusdi, si pedagang tersebut menyatakan bahwa sepeda tersebut dapat dibilang original karena pemakaiannya masih berjalan sekitar 6 bulan dari tangan pertama. Selain dari segi body atau fisik, mesin sepeda motor

${ }_{26}$ Rusdi, pembeli sepeda motor bekas, wawancara langsung pada tanggal 18 januari 2019 pukul 14:44 wib.

27 "Ahmad, penjual sepeda motor bekas, pada saat wawancara langsung, pada tanggal 20 januari 2019 pukul 09:23 wib.

28 Mahrus, penjual sepeda motor bekas, wawancara langsung, pada tanggal 21 januari 2019 pukul 15:43 wib. hal senada juga disampaikan oleh wahyudi dan rusdi, pembeli sepeda motor bekas saat wawancara langsung pada tanggal 22 januari 2019 pukul 10:02 wib. 
tersebut juga masih bagus. Akan tetapi setelah 1 bulan kemudian, ternyata Rusdi menemukan adanya kerusakan yang cukup serius pada bagian mesin sepeda motor. Hal itu yang membuat Rusdi sebagai pembeli merasa kecewa, sebab barang pesanannya tidak sesuai dengan perjanjian diawal. ${ }^{29}$ Hal yang sama juga dialami oleh Abdul Gani ${ }^{30}$ dan Mishadi ${ }^{31}$ selaku pembeli sepeda motor bekas.

Mengenai jagka waktu pemesana sampai barangnya datang memang ditentukan oleh si pembeli, tetapi tidak semua barang yang pesan mudah didapat di pasaran. Untuk sepeda motor yang masih terhitung baru, biasanya penjual menjanjikan kurang lebih 1 bulan. Sementara untuk sepeda motor yang sudah lama dan mudah didapat di pasaran, penjual biasanya menjanjikan sekitar 2 minggu. ${ }^{32}$

Pada dasarnya, jangka waktu pemesanan sepeda motor memang ditentukan oleh pembeli. Namun demikian jika sepeda motor yang dipesan masih tergolong baru, dan tidak mudah

29 Rusdi, pembeli sepeda motor bekas, wawancara langsung, pada tanggal 22 januari 2019 pukul 14:22 wib.

30 "Saya dulu pernah membelikan sepeda motor anak saya. saya dan pedagang sudah sama-sama sepakat spesifikasi barang sekaligus mengenai jangka waktunya. akan tetapi setelah sampai pada jangka waktu yang disepakati, si pedagang belum juga menyerahkan sepeda motor yang saya pesan. selang beberapa hari si pedagang baru datang membawa sepeda motor v-ixion dengan warna yang tidak sesuai dengan permintaan saya di awal. meski saya sudah protes, si pedagang tetap tidak mau tahu karena sepeda motor sudah terlanjur dibeli dan warna yang sesuai permintaan diawal tidak ada dipasaran. akhirnya mau tidak mau terpaksa saya harus menerimanya karena kebutuhan mendesak untuk anak saya pergi sekolah. wawancara secara langsung pada tanggal 24 januari 2019, pukul 11:14 wib.

31 Pada saat saya membeli sepeda motor, pada saat pemesanan, saya dan pedagang sudah sepakat mengenai harganya. Akan tetapi setelah sepeda motor tersebut datang, si pedagang meminta uang tambahan senilai Rp. 700.000 dengan alasan sepeda motor tersebut kualitasnya sangat bagus dan harga pasarannya sedang naik. Akan tetapi saya hanya memberinya tambahan Rp. 300.000. Wawancara langsung pada tanggal 24 Januari 2019, pukul 15:02 WIB.

32 Ahmad, penjual sepeda motor bekas, wawancara langsung, pada tanggal 29 januari 2019 pukul 08:22 wib. hal yang sama juga disampaikan mahrus, penjual sepeda motor bekas, pada saat wawancara langsung, pada tanggal 29 januari 2019 pukul 15:11 wib. 
Transaksi Jual Beli Sepeda Motor Bekas dengan Akad Salam di Desa Tamberu Laok

didapatkan di pasaran, pedagang meminta jangka waktu 1 bulan karena khawatir tidak langsung dapat mendapatkan barang pesanan tersebut di pasaran. Artinya, dalam kondisi seperti inilah pedagang juga berhak menegosiasikan tentang waktu dengan pembeli. Berbeda halnya jika ternyata sepeda motor yang dipesan sudah cukup lama dan mudah didapatkan di pasaran, maka pedagang memberi jangka waktu paling lama 2 minggu kepada pembeli.

Berdasarkan uraian diatas, tentang praktik jual beli sepeda motor bekas di Desa Tamberu Laok, sekurang-kurangnya menunjukkan tujuh hal yang akan penulis rangkum sebagai berikut: pertama, dalam praktik jual beli sepeda motor bekas, umumnya masyarakat memesan terlebih dahulu melalui pedagang, karena mereka meyakini bahwa pedagang yang lebih mengetahui masalah sepeda motor, meskipun ada yang datang langsung ke sorum. Kedua, jika melalui pedagang, maka pembeli harus membayar DP terlebih dahulu sekitar 50\% atau secara kontan. Ketiga, pembeli merasa kecewa dan tidak puas karena ternyata kualitas sepeda motor yang di pesan tidak sesuai dengan kesepakatan awal dan diketahui setelah beberapa bulan kemudian. Keempat, pembeli merasa dirugikan karena sepeda motor yang diserahkan tidak sesuai dengan pesanannya, baik ketidaksesuaian warna maupun striping. Kelima, pembeli keberatan karena pedagang masih meminta uang tambahan pada saat sepeda motor pesanannya diserahkan. Keenam, jangka waktu pemesanan sepeda motor ditentukan oleh pembeli, meskipun pedagang juga berhak menentukan dengan alasan-alasan tertentu. Ketujuh, transaksi jual beli sepeda motor bekas dengan akad salam di desa Tamberu Laok tidak sesuai karena bertentangan dengan sayarat dan rukun dalam jual beli akad salam.

\section{Pandangan Akad Salam}

Pada bagian ini penulis akan mengkaji atau menganalisis hasil penelitian lapangan yang sudah diuraikan diatas untuk mengetahui sejauh mana kesesuaian praktik jual beli tersebut dengan akad salam. Berangkat dari pemahaman bahwa akad salam adalah akad jual beli dimana barang yang diperjualbelikan belum ada ketika transaksi dilakukan. Akan tetapi pembeli memesan barang terlebih dahulu dengan menjelaskan spesifikasi dan kesepakatan-kesepakatan lainnya tentu saja. Selain itu, pembeli melakukan pembayaran dimuka 
meskipun barang pesanan baru diberikan dikemudian hari sesuai dengan kesepakatan.

Dalam praktik jual beli menggunakan akad salam yang sudah terjadi di desa Tamberu Laok, peneliti menemukan adanya ketidaksesuaian antara teori akad salam perspektif hukum Islam dengan praktik yang terjadi.

Akad salam secara etimologi artinya pendahuluan, dan secara muamalah adalah penjualan suatu barang yang disebutkan sifatsifatnya sebagai persyaratan jual beli dan barang yang dibeli masih dalam tanggungan penjual, di mana syaratnya ialah mendahulukan pembayaran pada waktu akad. Salam adalah akad jual beli barang pesanan antara pembeli dan penjual dengan pembayaran dilakukan di muka pada saat akad dan pengiriman barang dilakukan pada saat akhir kontrak. Barang pesanan harus jelas spesifikasinya. Spesifikasi barang telah disepakati oleh pembeli dan penjual di awal akad. Barang pesanan harus sesuai dengan karakteristik yang telah disepakati. ${ }^{33}$

Praktik jual beli sepeda motor bekas dengan akad salam di Desa Tamberu Laok, pihak pembeli juga melakukan pembayaran di awal dan barang (sepeda motor) akan diserahkan dikemudian hari sesuai dengan kesepakatan. Akan tetapi masyarakat desa Tmberu Laok mayoritas tidak mengetahui sistem akad salam, yang mereka pahami hanya jual beli sepeda motor bekas melalui pedagang dengan sistem pesanan.

Dalam pengamatan penulis, praktik jual beli sepeda motor bekas di desa Tamberu Laok sudah termasuk menggunakan akad salam, karena dalam praktiknya pembeli menyerahkan uang muka atau membayar separuh harga kemudian pembeli menjelaskan tentang jenis sepeda motor yang akan dipesan, dan pedagang menjelaskan harga pasaran sekaligus menentukan harga untuk jenis sepeda motor yang dipesan. Setelah itu, jika pihak penjual dan pembeli sepakat,maka kedua belah pihak menentukan masalah jangka waktu penyerahan barang pesanan.

Transaksi jual beli dengan akad salam dapat dikatakan sah apabila sudah memenuhi rukun dan syarat yang telah diuraikan dimuka. Hal itu diperkuat oleh ketentuan dalam Kompilasi Hukum

${ }^{33}$ Ismail, Perbankan Syariah.., hlm. 152. 
Ekonomi Syariah Pasal 100 s/d Pasal 103, bahwa bai' salam harus: 1) akad bai' salam terikat dengan adanya ijab dan kabul seperti dalam penjualan biasa. 2) akad bai' salam sebagaimana dimaksud pada ayat (1) dilakukan sesuai dengan kebiasaan dan kepatutan. 3) spesifikasi barang yang dipesan harus diketahui secara sempurna oleh para pihak. 4) bai' salam harus memenuhi syarat bahwa barang yang dijual, waktu, dan tempat penyerahan dinyatakan dengan jelas. 5) pembayaran barang dalam bai' salam dapat dilakukan pada waktu dan tempat yang disepakati. ${ }^{34}$

Sementara itu, ketentuan Fatwa Dewan Syariah Nasional Majelis Ulama Indonesia (DSN-MUI) Tentang Jual Beli Salam NO: 05/DSN-MUI/IV/2000 Tanggal 1 April Tahun 2000, adalah sebagai berikut:

Pertama, ketentuan tentang pembayaran. 1) Alat bayar harus diketahui jumlah dan bentuknya baik berupa uang, barang, atau manfaat. 2) Pembayaran harus dilakukan pada saat kontrak disepakati. 3) Pembayaran tidak boleh dalam bentuk pembebasan utang.

Kedua, ketentuan tentang barang. 1) Harus jelas ciri-cirinya dan dapat diakui sebagai utang. 2) Harus dapat dijelaskan spesifikasinya. 3) Penyerahan dilakukan dikemudian. 4) Waktu dan tempat penyerahan barang harus ditetapkan berdasarkan kesepakatan. 5) Pembeli tidak boleh menjual barang sebelum menerimanya. 6) Pembeli tidak boleh menukar barang, kecuali dengan barang yang sejenis sesuai kesepakatan.

Ketiga, penyerahan barang sebelum atau pada waktunya. 1) Penjual harus menyerahkan barang tepat pada waktunya dengan kualitas dan jumlah yang telah disepakati. 2) Jika penjual menyerahkan barang dengan kualitas yang lebih tinggi, penjual tidak boleh meminta tambahan harga. 3) Jika penjual menyerahkan barang dengan kualitas yang lebih rendah, dan pembeli rela menerimanya, maka ia tidak boleh menuntut pengurangan harga (diskon). 4) Penjual dapat menyerahkan barang lebih cepat dari waktu yang disepakati dengan syarat kualitas dan jumlah barang sesuai dengan kesepakatan, dan ia tidak boleh menuntut tambahan harga. 5) Jika semua atau sebagian barang tidak tersedia pada waktu penyerahan,

${ }^{34}$ M. Fauzan, Kompilasi Hukum Ekonomi Syariah.., hlm. 42. 
atau kualitasnya lebih rendah dan pembeli tidak rela menerimanya, maka ia memiliki dua pilihan: a) Membatalkan kontrak dan meminta kembali uanya, atau b) Menunggu sampai barang tersedia. ${ }^{35}$

Dari uraian diatas, dapat penulis simpulkan bahwa akad salam dalam transaksi jual beli di desa Tamberu Laok, yang juga dilihat dari sudut pandang Kompilasi Hukum Ekonomi Syariah, ternyata ada beberapa rukun yang tidak dipenuhi oleh pihak pedagang, yaitu spesifikasi barang. Meskipun pada saat pemesanan sepeda motor sudah dijelaskan mengenai kualitas dan jenis sepeda motor, akan tetapi pada saat pedagang meyerahkan sepeda motor, ternyata terdapat ketidakcocokan pada sepeda motor. Ketidakcocokan tersebut berada pada warna striping sepeda motor, sehingga pihak pembeli tidak puas bahkan merasa dirugikan, setelah mengetahui sepeda motor yang diterima tidak sesuai dengan pesanannya. Dengan demikian, maka dalam hal ini praktik jual beli dengan akad salam di desa Tamberu Laok tidak sesuai dengan Kompilasi Hukum Ekonomi Syariah (KHES).

Adapun rukun dan syarat yang tidak dipenuhi dari sudut pandang MUI yang tidak dipenuhi oleh pihak pedagang, yaitu meskipun pihak pedagang dan pembeli sudah membuat kesepakatan mengenai masalah harga sepeda motor, akan tetapi pada saat penyerahan pedagang masih meminta uang tambahan. Alasan pedagang meminta uang tambahan karena kualitas sepeda motor yang didapat sangat bagus dan harganya lebih tinggi dari harga pasar untuk sepeda motor sejenisnya. Dalam hal ini, praktik transaksi jual beli dengan akad salam di desa Tamberu Laok bertetangan dengan Fatwa MUI, karena ada beberapa rukun yang tidak dipenuhi dan dijalankan oleh pihak pedagang, dengan demikian hukumnya tidak boleh atau haram.

Sehubungan dengan hal tersebut, akad merupakan bentuk perikatan yang keberadaannya sangat penting untuk menentukan diterima atau ditolaknya suatu transaksi. Pada dasarnya, akad merupakan bentuk perbuatan yang dibolehkan (al-jawaz wal ibahah) atau bebas tanpa ikatan. Karena itu kebebasan berakad tergantung kepada bentuk yang dibenarkan syariat. Kebebasan akad dalam

35 Dewan Syariah MUI, Himpunan Keuangan Syariah (Penerbit Erlangga),. hlm. 71. 
Transaksi Jual Beli Sepeda Motor Bekas dengan Akad Salam di Desa Tamberu Laok

makna ini menyatakan bahwa setiap bentuk akad dipandang bebas untuk dilakukan selama rukun dan syarat melakukannya telah terwujud. Artinya, akad yang dilakukan dengan adanya unsur pemaksaan menjadi batal atau tidak sah. ${ }^{36}$

Dalam praktik yang terjadi di desa Tamberu Laok, dimana pedagang tidak memenuhi rukun dan syarat akad salam, karena pedagang sudah menyerahkan sepeda motor yang tidak sesuai dengan pesanan pembeli sehingga pihak pembeli merasa dirugikan karena barang yang diterima tidak sesuai keinginannya. Sebagaimana firman Allah dalam al-Qur'an, yang menyatakan betapa akad menjadi unsur penting yang harus dipenuhi dalam sebuah transaksi. Seperti yang dijelaskan pada QS. Al-Maa-idah (5): 1 yang Artinya : hai orang-orang yang beriman penuhilah akad-akad itu. ${ }^{37}$ Dan hadits Nabi SAW: Dari Abu Sa'id al-Khudriy bahwa Rasulullah SAW bersabda, "sesungguhnya jual beli itu harus dilakukan suka sama suka" (HR. AlBayhaqiy dan Ibnu Majjah, serta dinilai sahih oleh Ibnu Hibban). ${ }^{38}$

Setelah melihat firman Allah dan hadits Nabi diatas, pedagang sepeda motor di desa Tamberu Laok, sekali lagi, tidak memenuhi akad-akad yang sudah ditentukan oleh kedua belah pihak pada saat pemesanan, sehingga pihak pembeli merasa dirugikan. Hal itu sangat dilarang dan bertentangan dengan syariat Islam, karena pihak pedagang tidak memenuhi hak-hak yang dimiliki oleh pihak pembeli.

\section{Penutup}

Akad salam adalah akad jual beli barang pesanan antara pembeli dan penjual dengan pembayaran dilakukan di muka pada saat akad dan pengiriman barang dilakukan pada saat akhir kontrak. Barang pesanan harus jelas spesifikasinya. Spesifikasi barang telah disepakati oleh pembeli dan penjual di awal akad. Barang pesanan harus sesuai dengan karakteristik yang telah disepakati.

Dalam melakukan pembelian sepeda motor bekas, masyarakat Desa Tamberu Laok umunya membeli melalui pedagang dengan cara

${ }^{36}$ Ashbul Fadhli, "Tinjauan Hukum Islam Terhadap Penerapan Akad AsSalam Dalam Transaksi E-Commece," Jurnal Pemikiran Hukum Islam 15 (Juni 2016),. hlm. 3.

${ }^{37}$ Al-Qur'an, Al-Maa-idah (5): 1.

${ }^{38}$ Dewan Syariah MUI, Himpunan Keuangan Syariah.., hlm. 69. 
memesan terlebih dahulu. Mengenai masalah harga, ditentukan oleh pedagang berdasarkan jenis sepeda motor dan harga yang ada dipasaran. Jika sudah sepakat dengan harga, pembeli harus membayar separuh dari harga sepeda motor yang dipesanya. Untuk jenis sepeda motor, sudah ditetentukan pada saat pemesanan. Akan tetapi mengenai kualitasnya, ada pembeli yang kurang puas karena setelah beberapa lama pemakaian baru diketahui bahwa ada beberapa kerusakan pada mesin sepeda motor.

Pandangan Hukum Ekonomi Syariah terhadap praktik jual beli sepeda motor bekas di Desa Tamberu Laok, Kec. Sokobanah, Kab. Sampang, menunjukkan bahwa praktik tersebut dilarang dan jelas haram hukumnya, karena bertentangan dengan al-Qur'an dan hadits. Adanya ketidakcocokan antara barang yang sudah disepakati pada saat pemesanan dengan barang yang diterima oleh pembeli, mengafirmasi pertentangan itu. Disamping itu, hal tersebut juga bertentangan dengan Fatwa No:05/DSN-MUI/IV/2000 Tentang Jual Beli Salam.

\section{Daftar Pustaka}

Al-Qur'an, Al-Baqarah (2): 282.

Ascarya. Akad E Produk. Jakarta: PT. RajaGrafindo Persada, 2007.

Buna'i. Buku Ajar Metodologi Penelitian Pendidikan. Pamekasan: STAIN Pamekasan Press, 2006.

Djakfar, Muhammad. Hukum Bisnis. Malang: UIN Malang Press, 2009.

Fadhli, Ashbul. "Tinjauan Hukum Islam Terhadap Penerapan Akad As-Salam Dalam Transaksi E-Commece." Jurnal Pemikiran Hukum Islam 15 (2016).

Fauzan, M. Kompilasi Hukum Ekonomi Syariah. Jakarta: Kencana Pranada Media Group, 2009.

Gunawan, Imam. Metode Penelitian Kualitatif Teori \& Praktik. Malang: Bumi Aksara, 2013.

Haroen, Nasrun. Figh Muamalah. Jakarta: Gaya Media Pratama, 2007.

Huda, Qamarul. Fiqh Muamalah. Yogyakarta: Teras, 2011.

Ismail. Perbankan Syariah. Jakarta: Kencana Prenadamedia Group, 2011.

Mardani. Figh Muamalah. Jakarta: Kencana Prenadamedia Group, 2012.

Moleong, Lexi J. Metodologi Penelitian Kualitatif. Bandung: Remaja 
Transaksi Jual Beli Sepeda Motor Bekas dengan Akad Salam di Desa Tamberu Laok

Rosdakarya, 2014.

MUI, Dewan Syariah. Himpunan Keuangan Syariah. Erlangga.

Mujiatun, Siti. "Jual Beli Perspektif Islam Salam Dan Istishna." Jurnal Riset Akutansi Dan Bisnis 13 (2013): 207.

Muthaher, Osmad. Akutansi Perbankan Syariah. Yogyakarta: Graha Ilmu, 2012.

Octavia, Biuty Wulan. “Tinjauan Hukum Islam Terhadap Jual Beli Akad As-Salam Dengan Sistem On Line Di Pand's Collection Pandanaran." Institut Agama Islam Negeri Walisongo Semarang, 2011.

S, Burhanuddin. Hukum Kontrak Syariah. Yogyakarta: BPFEYogyakarta, 2009. 